\title{
THE OBLIGATION OF NATIONAL COURTS AGAINST WHOSE DECISION THERE IS NO JUDICIAL REMEDY TO REFER QUESTIONS TO THE COURT OF JUSTICE OF THE EUROPEAN UNION
}

\author{
Valentin Paul Neamt PhD \\ „Vasile Goldis" Western University of Arad \\ e-mail: valentinpaulnmt@gmail.com
}

(Received November 2015; Accepted January 2016)

\begin{abstract}
The present paper presents the obligation that courts in the member states of the European Union have to refer questions to the Court of Justice of the European Union, with a focus on courts against whose decision there is no judicial remedy under national law. The paper starts by presenting the applicable framework regarding the preliminary reference procedure, then focuses on analyzing the exceptions to national court's duty under article 267 TFEU, with a focus on the direction in which the case law is heading based on the most recent judgments handed down by the Court of Justice of the European Union in 2015, finally presenting the author's conclusions and observation on the subject.
\end{abstract}

Keywords: art. 267 TFEU, obligation to refer

The present paper strives to make an analysis of the relevant legislation, case-law and applicable concepts regarding the obligation that courts in the member states of the European Union (hereinafter referred to as "The EU") have to refer questions to the Court of Justice of the European Union (hereinafter referred to as "The CJEU" or "The Court"), with a focus on courts against whose decision there is no judicial remedy under national law. The paper starts by presenting the applicable framework regarding the preliminary reference procedure, and continues by presenting the initial changes to the member states' strict obligation to refer questions to the CJEU in certain circumstance. The third part focuses on recent CJEU judgments which seem to dilute the Member States obligation regarding referring questions, while the final part presents the author's conclusions.

\section{Legal framework and initial application}

Art. 267 of the Treaty on the Functioning of the European Union (hereinafter referred to as "the TFEU")

"The Court of Justice of the European Union shall have jurisdiction to give preliminary rulings concerning:

(a) the interpretation of the Treaties;

(b) the validity and interpretation of acts of the institutions, bodies, offices or agencies of the Union; 
The obligation of national Courts against whose decision there is no judicial remedy to refer questions to the Court of Justice of the European Union

Where such a question is raised before any court or tribunal of a Member State, that court or tribunal may, if it considers that a decision on the question is necessary to enable it to give judgment, request the Court to give a ruling thereon. Where any such question is raised in a case pending before a court or tribunal of a Member State against whose decisions there is no judicial remedy under national law, that court or tribunal shall bring the matter before the Court."

The justification of the preliminary reference procedure is that the EU, being a supra-national legal system can only operate as a whole, across a number of very different legal systems if the legal concepts set out by the European institutions are applied in the same way across the many jurisdictions where European law applies. As one author noted" If particular provisions of EU law could not be referred, both the uniformity and autonomy of the legal order would be compromised, as, without authorative guidance, national courts would give divergent interpretations and the sense of being part of the same legal jurisdiction would be compromised.[1]" Another respected legal opinion stated that " $[\mathrm{t}]$ he development of the preliminary ruling system has therefore enrolled national courts as part of the EU judicial system broadly conceived, with both the power and duty to apply EU law in cases that come before them. This has been crucial in making the system 'work'. [2]'"

Initially, the common interpretation of the quoted article was that any court against whose decision there is no judicial remedy under national law must indeed refer any question regarding the interpretation of European law to the CJEU, regardless of the circumstances. This has, of course created a huge backlog of cases referred to the CJEU, making the management of the preliminary reference procedure difficult, to say the least. More so, the CJEU was starting to be put in a position where it either had to give interpretations of European law that had already been answered in other judgments or give interpretations in cases where the answer to the question asked was so obvious that it left no room for interpretation. A great example is the question posed n Cilfit [3], which will be further discussed in the following. In that particular case the Court of Cassation of Italy was presented with a case in which it had to decide if wool products should be classified as an animal product in the meaning of Regulation (EEC) No827/68 of 28 June 1968 on the common organization of the market in certain products listed in Annex II to the Treaty. Before the Court's judgments on limitations to the duty of courts to refer questions to the CJEU, the conventional wisdom was that such a question, no matter how obvious the answer, needed to be referred to the CJEU.

\section{Initial limits of the obligation to refer}

The CJEU limited this responsibility in two cornerstone judgments. In Da Costa [4], the CJEU was referred questions regarding the direct effect of then article 12 of the Treaty Establishing the European Community and the way of 


\section{JOURNAL OF LEGAL STUDIES}

"Vasile Goldiș" Western University of Arad

Neamt, V.P. (2016)

The obligation of national Courts against whose decision there is no judicial remedy to refer questions to the Court of Justice of the European Union

ascertaining if custom duties or measures having an equivalent effect had been raised by the member states in a way contrary to the treaty.

As the matters referred for a preliminary ruling had already been the object of another preliminary reference, already answered by the court, it ruled that "Although the third paragraph of Artic le [267] unreservedly requires courts or tribunals of a Member State against whose decisions there is no judicial remedy under national law ... to refer to the Court every question of interpretation raised before them, the authority of an interpretation under Article [267] already given by the Court may deprive the obligation of its purpose and thus empty it of its substance. Such is the case especially when the question raised is materially identical with a question which has already been the subject of a preliminary ruling in a similar case." This was the start of the "acte eclaire" doctrine.

In Cilfit, as was presented above, the case pending before the national court seemed to have a very obvious solution. Indeed, the Court of Cassation's question had less to do with the circumstances of the case before as it had to do with its particular obligation in such cases. Based on the wording of the treaty article, the Court considered that, except for cases like DaCosta, it was indeed obliged to make a reference if a request to make a preliminary ruling was lodged before it.

The referred question was:" Does the third paragraph of Article 177 ofthe EEC Treaty, which provides that where any question of the same kind as those listed in the first paragraph of that article is raised in a case pending before a national court or tribunal against whose decisions there is no judicial remedy under national law that court or tribunal must bring the matter before the Court of Justice, lay down an obligation so to submit the case which precludes the national court from determining whether the question raised is justified or does it, and if so within what limits, make that obligation conditional on the prior finding of a reasonable interpretative doubt? [5]"

The Court expanded upon Da Costa. First of all, the Court emphasized that the sole fact that the parties raise a question regarding the interpretation of European law before any national court against whose decision there is no remedy under national law does not oblige the court to make a reference, the court must consider the question relevant, which means that the answer to the question may affect the outcome of the case.

Secondly, the court reasserted the acte eclaire doctrine, stressing that the doctrine applies where the European Courts "have already dealt with the point of law in question, irrespective of the nature of the proceedings which led to those decisions, even though the questions at issue are not strictly identical [6]".

Thirdly the, CJEU held that in some cases "the correct application of Community law may be so obvious as to leave no scope for any reasonable doubt as to the manner in which the question raised is to be resolved [7]." In such cases the court 
Neamt, V.P. (2016)

The obligation of national Courts against whose decision there is no judicial remedy to refer questions to the Court of Justice of the European Union

is not obliged to refer a question to the Court. This constitutes the so-called "acte clair" doctrine.

However, the Court advised caution stating that "Before it comes to the conclusion that such is the case, the national court or tribunal must be convinced that the matter is equally obvious to the courts of the other Member States and to the Court of Justice. [8]" It emphasized that EU legislation is drafted in several language versions, all of them equally authentic, any interpretation implying an analysis of different language versions. Secondly, the terminology used is peculiar to European law; the meaning of legal concepts may differ from their interpretation under national law. Thirdly, any interpretation of European law must be made in the context of the treaties and EU law in General.

\section{Further developments}

The consequences of the freedom given to national courts weren't immediately apparent. Now that the courts didn't have an obligation to refer questions regarding national law, the prospect of final decisions which are contrary to European law became a real possibility.

That possibility materialized in Kobler [9]. The case concerned a ruling made by the Austrian Supreme Court which was in breach of European law. Without going into the substantive law implied, to sum up: a German national was deprived of his rights under European law because the Austrian courts, including the Austrian Supreme Court failed to refer a question to the CJEU in the concerned matter, relying on an interpretation given by the court in a similar matter. While the court did initially submit a preliminary reference, the request was withdrawn, the Supreme Court being confident that an interpretation given in a similar case was sufficient to give a ruling.

The CJEU first ruled on the interpretation of the legal text that formed the basis for the Supreme Court's decision. It found that, in fact, the Supreme Court's interpretation was not correct and that the legal texts relied upon should have been interpreted in a different manner.

The referring court also asked if a Member State might be liable for damages as a consequence of a judicial error made by a court against whose decision there is no judicial remedy under national law. The CJEU found that a Member State is liable for damages caused to private persons as a consequence of judgments handed down by national courts, including a member state's Supreme Court. The doctrine of state liability first developed by the court in Brasserie du Pecheur and Factortame [10] also extends to liability for infringements stemming from judicial errors. The court held that "the principle that Member States are obliged to make good damage caused to individuals by infringements of Community law for which they are responsible is also applicable where the alleged infringement stems from a decision 


\section{JOURNAL OF LEGAL STUDIES}

"Vasile Goldiș" Western University of Arad

Neamt, V.P. (2016)

The obligation of national Courts against whose decision there is no judicial remedy to refer questions to the Court of Justice of the European Union

of a court adjudicating at last instance where the rule of Community law infringed is intended to confer rights on individuals, the breach is sufficiently serious and there is a direct causal link between that breach and the loss or damage sustained by the injured parties. In order to determine whether the infringement is sufficiently serious when the infringement at issue stems from such a decision, the competent national court, taking into account the specific nature of the judicial function, must determine whether that infringement is manifest. It is for the legal system of each Member State to designate the court competent to determine disputes relating to that reparation. [11]"

Kobler demonstrated that the initial aim of provisions 267, the prevention of any case law that is contrary to the "official" interpretation of European law ever coming into existence inside a Member State had not been achieved. By watering down the requirements of making a preliminary reference, the CJEU enabled a disharmonized interpretation of European law. The doctrine of state liability did offer those whose rights were infringed the possibility of an effective remedy, if indeed the infringement has been manifest.

Further clarifications regarding the obligation of a court or tribunal against whose decision there is no judicial remedy to refer a question to the CJEU were given in Intermodal Transports [12]. The case involved a question referred by the Netherlands regarding a differing interpretation of community legislation by the authorities of two different Member States. The court asked, if in the particular circumstances, taking into account the possibly serious consequences of the situation and the pan-European dimensions of the contradicting views, in such a case a court against whose decision there is no judicial remedy is obliged to make a reference to the CJEU, asking for clarification of the subject.

The CJEU's judgment supported national courts' freedom to decide. It stated that objective circumstances such as those mentioned in the reference for a preliminary ruling could not oblige a court to make a preliminary ruling if, by the court's own consideration, the conditions outlined in the Cilfit judgment are fulfilled, the question being either already solved by the CJEU in a similar action or the solution being so obvious as not to require an interpretation by the CJEU.

However, the judgment did contain a cautionary note to the Member States, stating that "the case-law as stated in Cilfit and Others gives the national court sole responsibility for determining whether the correct application of Community law is so obvious as to leave no scope for any reasonable doubt and for deciding, as a result, to refrain from referring to the Court of Justice a question concerning the interpretation of Community law which has been raised before it" [13].

In $X$ and Dijk [14] the Court again had to rule regarding the obligation of a court against whose decision there is no remedy under national la to refer a question to the CJEU. The relevant question is the following: "Is the Hoge Raad der 
Neamt, V.P. (2016)

The obligation of national Courts against whose decision there is no judicial remedy to refer questions to the Court of Justice of the European Union

Nederlanden, as the highest national court, required, because of a question referred for a preliminary ruling by a lower national court, to refer a question to the Court of Justice for a preliminary ruling or must it await the answer to that question referred by the lower national court, even if it takes the view that the correct application of EU law on the matter to be decided by it is so obvious as to leave no scope for any reasonable doubt as to how that question must be answered". In essence, the issue was if a Supreme Court allowed concluding that the answer to a question referred for a preliminary ruling by a lower court was so obvious as to leave no room for interpretation, in the meaning of Cilfit.

The Court's ruling again gave national courts liberty, stating that: "it must be borne in mind that it is solely for the national court before which the dispute has been brought, and which must assume responsibility for the subsequent judicial decision, to determine in the light of the particular circumstances of the case both the need for a preliminary ruling in order to enable it to deliver judgment and the relevance of the questions which it submits to the Court". While the CJEU considered that a Supreme Court must bear in mind that a lower court made a reference, the court must "take upon themselves independently the responsibility for determining whether the case before them involves an 'acte clair' [15]."

Ferreira da Silva [16] is the most recent case that deals with this particular subject matter. This time, several lower courts in Portugal had given diverging opinions regarding the interpretation of a transfer of business in the light of European law. When one of these cases came before the Portuguese Supreme Court, the parties made a request for a preliminary ruling to the CJEU. The Court refused stating that 'there was 'no material doubt' as to the interpretation of the rules 'which would make a reference for a preliminary ruling necessary" [17].

The applicants in the main proceedings then brought an action for a declaration of non-contractual civil liability against the Portuguese State, claiming that the latter should be ordered to pay damages for certain material loss they had sustained. The lower court then referred a set of question to the Court of Justice asking, inter alia:

"Must Article 267 TFEU be interpreted as meaning that, in the light of the facts set out in the first question and the fact that the lower national courts adjudicating on the case adopted contradictory decisions, the Supremo Tribunal de Justiça was under an obligation to refer to the Court for a preliminary ruling the question of the correct interpretation of the concept of a "transfer of a business" within the meaning of Article 1(1) of Directive 2001/23?"

One important point is the interpretation given by the Portuguese Supreme Court. In deciding the case, the court concluded that in the present case there had not been a "transfer of business" in the meaning of European law and subsequently dismissed the action. 


\section{JOURNAL OF LEGAL STUDIES}

"Vasile Goldiș" Western University of Arad

Neamt, V.P. (2016)

The obligation of national Courts against whose decision there is no judicial remedy to refer questions to the Court of Justice of the European Union

The referring Court's first answer was that, in fact, in the present circumstances there had been a transfer of business in the meaning of Directive 2001/23. While a presentation of the material law regarding to the concept of transfer of business in the meaning of Directive 2001/23 is beyond the scope of the present paper, we would like to point out the fact that the Portuguese Supreme Court's interpretation was, in fact, not in line with the interpretation given by the CJEU.

In relations to the second question referred for a preliminary ruling, the Court first dealt with the issue of conflicting judgments made by lower courts. Regarding this aspect, the Court was very brief and simply stated that:

"In itself, the fact that other national courts or tribunals have given contradictory decisions is not a conclusive factor capable of triggering the obligation set out in the third paragraph of Article 267 TFEU.

A court or tribunal adjudicating at last instance may take the view that, although the lower courts have interpreted a provision of EU law in a particular way, the interpretation that it proposes to give of that provision, which is different from the interpretation espoused by the lower courts, is so obvious that there is no reasonable doubt. [18]"

And then the following paragraph seems to make the situation confusing. The CJEU stated that:

"However, so far as the area under consideration in the present case is concerned and as is clear from paragraphs 24 to 27 of this judgment, the question as to how the concept of a 'transfer of a business' should be interpreted has given rise to a great deal of uncertainty on the part of many national courts and tribunals which, as a consequence, have found it necessary to make a reference to the Court of Justice. That uncertainty shows not only that there are difficulties of interpretation, but also that there is a risk of divergences in judicial decisions within the European Union.

It follows that, in circumstances such as those of the case before the referring court, which are characterized both by conflicting lines of case-law at national level regarding the concept of a 'transfer of a business' within the meaning of Directive $2001 / 23$ and by the fact that that concept frequently gives rise to difficulties of interpretation in the various Member States, a national court or tribunal against whose decisions there is no judicial remedy under national law must comply with its obligation to make a reference to the Court, in order to avert the risk of an incorrect interpretation of EU law. [19]"

What can we infer from the parallel reading of those paragraphs? If there are conflicting judgments, the court is not under a duty to make a reference for this reason alone. However, if there are conflicting judgments and there is a concept that often gives difficulties of interpretation in the various Member States, there is an obligation to refer. It seems from the Court's judgment that it continues on its trend of not obliging the Member State's courts against whose decision there is no 
Neamt, V.P. (2016)

The obligation of national Courts against whose decision there is no judicial remedy to refer questions to the Court of Justice of the European Union

judicial remedy, in fact, usually the Member State's Supreme Courts to refer questions based solely on objective grounds, giving them plenty of freedom $n$ deciding when to refer a question to the CJEU.

\section{Conclusions}

Dacosta and Cilfit can be seen as perfectly reasonable judgments with seemingly no ill circumstances. If the point of article 267 is to assure uniform interpretation of European law in all the Member States, it is obvious that referring questions that have already been answered, questions irrelevant to the concrete cases being judged by the national courts or questions with obvious answers has no practical point. It was reasonable to give national court the means of escaping the obligation to refer in cases where it held no benefit, neither for the courts, nor for the EU legal order.

Regarding the original purpose of art. 267, as stated by the CJEU in the context of CILFIT, namely that it "seeks to prevent the occurrence within the Community of divergences in judicial decisions on questions of Community law [20]", the Court seems to have taken a more lax approach.

Once such case law did appear, the CJEU seemed concerned only with the right of injured persons to claim damages. Now that redress is at least theoretically available to people whose European law rights have been infringed by national courts, without the possibility of judicial remedy, the CJEU seems more inclined to let the member states and private plaintiffs resolve their own issues, without it being necessary for the court to oblige them to come before it with a preliminary ruling.

First of all, in Cilfit, the CJEU expressed the view that in order for the doctrine of acte clair to apply the national court must come to the conclusion that the matter is equally obvious to the courts of the other Member States and to the Court of Justice.

How is that view reconciled with the more recent judgments?

Firstly, regarding the Intermodal Transports case, the CJEU stated that " $[\mathrm{t}] \mathrm{he}$ fact that the customs authorities of another Member State have issued to a person not party to the dispute before such a court and in respect of similar goods to those at issue in that dispute a BTI as referred to by a provision of secondary legislation such as Article 12 of the CCC cannot limit the freedom of assessment thus vested in that court under Article 234 EC [21]".

How is that to be reconciled with the requirement of a matter being equally clear to the court of other Member States or to the Court of Justice?

The Advocate - General, in her opinion stated that:" First, it must be noted that the 'obviousness' of a correct interpretation is not generally contradicted by the fact that a provision can clearly be read in 'two' ways, because, as I have already stated,

DE GRUYTER OPEN 


\section{JOURNAL OF LEGAL STUDIES}

"Vasile Goldiș" Western University of Arad

Neamt, V.P. (2016)

The obligation of national Courts against whose decision there is no judicial remedy to refer questions to the Court of Justice of the European Union

a provision can never 'per se' be unambiguous and clear; an element of decisionmaking or judgment, in other words an element of subjectivity, is to varying degrees inherent in the act of interpretation [22]." This fact was called a "caveat", something simply to be taken in consideration by the court when deciding to make a reference or not.

Secondly, regarding $\mathrm{X}$ and Dijk, the Advocate General's opinion points the requirement in more relativistic terms. Advocate-general Wahl states that: "[the] requirement cannot be understood in absolute terms. Rather, it should be understood as meaning that the judges of final appeal ruling upon the matter must be convinced, in their minds that other judges would agree with them. As I see it, the circumstances mentioned in paragraphs 16 to 20 of the judgment in Cilfit and others constitute a 'tool kit' for determining whether or not there might be any reasonable doubt. They are to be seen as warning signs rather than strict criteria and, read fairly, amount to no more than common sense. So, (...) I find myself unable to read Cilfit and Others as stating that reasonable doubt can be measured objectively merely by pointing to differences of interpretative opinion among members of the judiciary.

In this sense, it seems less important to me whether potential disagreement might come from a judge from another Member State or a judge from the same Member State. (...)

So in essence, my view boils down to this: if a national court of last instance is sure enough of its own interpretation to take upon itself the responsibility (and possibly the blame) for resolving a point of EU law without the aid of the Court of Justice, it ought to be legally entitled to do so. But, in such a situation, there is a fly in the ointment: the prospect that legal action might be taken against the Member State of the court of last instance for failure to refer and/or incorrect application of EU law. That is a risk which that court must assume alone [23]."

Regarding Ferreira de Silva, the Court's rhetoric seems to take the same stance. It is for the national court to decide if it considers necessary to refer a question to the CJEU or take responsibility for its own decisions.

While advocate-general Wahl maintains that the recent cases are not a departure from the Cilfit doctrine, I consider it obvious that Cilfit would not have permitted such a huge leap from the duty to refer originally encompassed. The original purpose of the article was to prevent divergence from the norms, reducing it to a "toolkit" and mere warning signs is no, in my opinion, what the Cilfit judgment was about.

Regarding the justification for this departure, I think several clues can be found in the Advocate-General's opinion in Intermodal Transport [24]:

"Accordingly, the rule in Cilfit could be called into question in its entirety. (...) 
Neamt, V.P. (2016)

The obligation of national Courts against whose decision there is no judicial remedy to refer questions to the Court of Justice of the European Union

While the Cilfit criteria discussed above may be imprecise in terms of their specific meaning, it is likely to be too difficult to define, on the basis of the Treaty, a more practicable or more objective 'filter system' for questions of interpretation which should be referred to the Court of Justice, on the one hand, or left to the national courts of last instance, on the other. For example, the proposal put forward by Advocate General Jacobs in Wiener, that the 'conditions' referred to in the judgment in Cilfit should apply only where there is a general question and where there is a genuine need for uniform interpretation, is undoubtedly aimed at the type of questions which first and foremost require clarification by the Court of Justice. In my view, however, determining the importance of a question and the need for uniform interpretation for the purposes of Community law creates additional difficulties from the point of view of national courts of last instance and blurs even further the scope of their discretion.

However, even if the Court of Justice succeeded in formulating criteria in relation to the obligation of courts of last instance to make a reference for a preliminary ruling which were clearer than those set out in the judgment in Cilfit, permitting national courts of last instance to rule independently on questions of interpretation would inevitably still entail a degree of discretion, in other words an element of subjectivity. The only way to tell with certainty whether an interpretation which a national court of last instance has given to a particular measure and regards as being 'beyond doubt' is 'correct' is, ultimately, by reference to (its conformity with) a judgment, if any, of the Court of Justice. (...)

From a practical point of view, however, it must be borne in mind - although this ought not to be decisive - that even the simplified processing of references for preliminary rulings by the Court of Justice in dialogue with the national courts takes up time proceedings. Moreover, despite all the misgivings and the fact that the 'Cilfit system' is open to challenge in principle, the question must be raised whether the Court of Justice can fulfill its task of enforcing the law in the interpretation and application of the Treaty, in a Union of 25 Member States which has an ever-growing Community acquis, without trusting the judgment - in the truest sense of the word - of the national courts, at least within certain limits, even though such a division of functions can lead to difficulties in practice.[25]"

In reference of the above, it seems clear that, firstly, this new-found freedom for the Supreme Courts of Member States is based upon a very practical consideration: the CJEU, in the opinion of one of its advocate-generals at the time would not be equipped to deal with such a very large number of preliminary rulings. The fact that the Court's docket is overloaded is not a new occurrence. The more cases, the more difficult it is to give a national curt a preliminary ruling in a reasonable time windows. Based on the CJEU's latest available statistics [26], the current waiting time for a preliminary ruling is 15 months in the year 2014, which is a record. In 


\section{JOURNAL OF LEGAL STUDIES}

"Vasile Goldiș" Western University of Arad

Neamt, V.P. (2016)

The obligation of national Courts against whose decision there is no judicial remedy to refer questions to the Court of Justice of the European Union

2014 the Court still had a number of 787 cases pending, a decrease from the maximum of 886 pending cases it had in 2012.

Another point needs to be made regarding the risks associated with the appearance of diverging judgments in national case law. It must be borne in mind that the original judgment in Cilfit was given in the year 1982. More than thirty years later, the acquis communautaire has grown and much of its nucleus has been established. Given the sheer number of judgments given by the CJEU, certain aspects of EU law are definitely settled and the risk of creating divergent interpretations regarding the core of the Union has been significantly reduced. While early divergence might have meant a complete defeat of the legal system itself, current discrepancies can only mean lack of clarity regarding some concrete issues and cannot endanger the legal order.

Thirdly, since Kobler gives plaintiffs the right to obtain reparation, as we can see from the recent judgments, the Court is starting to put the emphasis on a national court's responsibility and not on its duty. The matter seems to revolve more around protecting the rights of those affected by the decision and emphasizing the prospects of state liability than to revolve around the court's duty to the European Union. This confirms the fact that any threat to the legal order itself is minimal and that the only parties in danger are the people standing before the national court or the member state itself, which may have to pay damages for any errors on the part of the court.

The general conclusion is that the duty to make a preliminary ruling seems to have profoundly evolved since the initial Dacosta and Cilfit judgments, in tune with the changes taking place in the Union itself. Since the CJEU doesn't seem to consider national case-law as being a big threat to the European legal order, I consider it likely that this lax approach will continue, at least until the CJEU's docket will have become more manageable. If that ever happens, the Court might have a change of heart, but considering that European laws has already established itself and that there are mechanism for obtaining reparation in the case of judicial errors, I find the possibility very remote.

\section{Notes}

[1] Damian Chalmers, Gareth Davies, Giorgio Monti - European Union Law: Cases and Materials 2nd Edition, Oxford University Press, Oxford, 2010, page 160.

[2] Paul Craig, Grainne de Burca - EU Law: Text, Cases, and Materials, 5th Edition, Oxford University Press, Oxford, 2011, page 477.

[3] Case 283/81 - Srl CILFIT and Lanificio di Gavardo SpA v Ministry of Health (1982), ECR 03415 .

[4] Joined Cases 28 to 30/62 - Da Costa v Nederlandse Belastingadministratie (1963) ECR 31

[5] Cilfit, cited above, para. 4. 
Neamt, V.P. (2016)

The obligation of national Courts against whose decision there is no judicial remedy to refer questions to the Court of Justice of the European Union

[6] Cilfit - para. 14

[7] Cilfit - para. 16

[8] Ibid.

[9] Case C-224/01 - Gerhard Kobler v Republic of Austria (2003), ECR 2003 I-10239.

[10] C-46/93 - Brasserie du Pecheur and Factortame (1996) ECR I-1029.

[11] Para. 59

[12] C-495/03 - Intermodal Transports BV v Staatssecretaris van Financien (2005), ECR I08151 .

[13] Intermodal Transports, cited above, para. 37.

[14] Joined Cases C-72/14 and C-197/14 - X v Joined Cases C-72/14 and C-197/14 and T.A. Van Dijk v Staatssecretaris van Financien, not yet reported.

[15] Joined cases X and Dijk, cited above, para. 59.

[16] Case C-160/14 - João Filipe Ferreira da Silva e Brito and Others v Estado portugues, not yet reported.

[17] Ibid., Para. 16

[18] Paras. 42 and 43

[19] Ibid., para. 44.

[20] Cilfit, cited above, para. 7.

[21] Intermodal Transports, cited above, para. 32.

[22] Opinion of Advocate General Stix-Hackl delivered on 12 April 2005 in Case C-495/03

- Intermodal Transports BV v Staatssecretaris van Financien, para. 110.

[23] Ibid, paras. $67-69$.

[24] Opinion of Advocate General Wahl delivered on 13 May 2015 - Joined Cases C-72/14 and C-197/14 X and T.A. van Dijk, para.

[25] Ibid., paras $103-107$.

[26] Statistics concerning judicial activity in 2014, available at http://curia.europa.eu/jcms/upload/docs/application/pdf/2015-03/cp150027en.pdf, last accessed on the $30^{\text {th }}$ of November 2015 .

\section{Bibliography}

1. Damian Chalmers, Gareth Davies, Giorgio Monti - European Union Law: Cases and Materials 2nd Edition, Oxford University Press, Oxford, 2010;

2. Paul Craig, Grainne de Burca - EU Law: Text, Cases, and Materials, 5th Edition, Oxford University Press, Oxford, 2011;

3. Statistics concerning judicial activity in 2014 , available at http://curia.europa.eu/jcms/upload/docs/application/pdf/2015-03/cp150027en.pdf, last accessed on the 30th of November 2015.

Judgments of the Courte of Justice of the European Union:

4. Case 283/81 - Srl CILFIT and Lanificio di Gavardo SpA v Ministry of Health. [1082], ECR 03415;

5. Joined Cases 28 to 30/62 - Da Costa v Nederlandse Belastingadministratie [1963] ECR 31; 
Neamt, V.P. (2016)

The obligation of national Courts against whose decision there is no judicial remedy to refer questions to the Court of Justice of the European Union

6. Case C-224/01 - Gerhard Kobler v Republic of Austria [2003], ECR 2003 I10239;

7. Case C-46/93 - Brasserie du Pecheur and Factortame [1996] ECR I-1029;

8. C-495/03 - Intermodal Transports BV v Staatssecretaris van Financien [2005], ECR I-08151;

9. Joined Cases C-72/14 and C-197/14 - X v Joined Cases C-72/14 and C197/14 and T.A. Van Dijk v Staatssecretaris van Financien, not yet reported.

10.Case C-160/14 - João Filipe Ferreira da Silva e Brito and Others v Estado portugues, not yet reported.

Advocate-General's opinions:

11.Opinion of Advocate General Stix-Hackl delivered on 12 April 2005 in Case C495/03 - Intermodal Transports BV v Staatssecretaris van Financien;

12. Opinion of Advocate General Wahl delivered on 13 May 2015 - Joined Cases C $-72 / 14$ and C-197/14 X. 